\title{
Linguistic Landscape: A Language Learning Media in An Underdeveloped Region
}

\author{
Agus Riadi1, Fransiska Way Warti ${ }^{1}$ \\ ${ }^{1}$ Politeknik Tonggak Equator, Indonesia
}

Abstract: As the result of the implementation of the latest curriculum in Indonesia, namely curriculum 2013, some problematic issues have arisen in its application. The apparent facts of this are the reduced number of hours dedicated to the subject of English, and the hampered distribution of the curriculum properties in rural areas, such as textbooks and teacher training for the curriculum. To resolve this dilemma, there is a need to find another means for teachers in rural areas to teach English, for example by using the authentic and contextual English text that is dispersed in their surroundings (Linguistic Landscape). Therefore, the aims of this research are to investigate the LL as a form of English exposure that students may encounter around their school neighbourhood, and the English language teachers' perception of $L L$ if it is to be applied as an additional learning resource, taking as an example a school in one underdeveloped region such as in Pulau Maya, Kayong Utara-West Borneo. This research employed a qualitative method by using an educational case study to investigate the teachers and the environment of this sample school. The data were obtained in the form of photographs and interviews. From the analysis, it was found that there are abundant LL signs that could promote students' learning of English in improving their vocabulary, pragmatic competence, multimodal literacy, grammatical features, and their understanding of social aspects. Despite some sceptical perceptions, most of the teachers also seemed to acknowledge the apparent advantages of using $L L$ in their future teaching.

Keywords: Linguistic landscape, ELT, Underdeveloped region

\section{INTRODUCTION}

Under the Ministry of Education and Cultures, Indonesia has implemented a new curriculum, called Curriculum 2013 (hence, K-13). Within this curriculum, the Indonesian government has established English as a compulsory subject in both junior and senior secondary schools across the nation (Kemendikbud, 2013). However, despite its obvious benefits, the implementation of such a policy might also be problematic. One of the obstacles that may arise is the unequal distribution of curriculum properties (i.e. curriculum training, learning materials, etc.) across every part of the country, considering the vast area involved, and other technical problems.

Pulau Maya, Kayong Utara - one of Indonesia's underdeveloped regions is located in West Borneo (Setkab, 2015). With around a hundred thousand inhabitants, Kayong Utara has twenty-one secondary high schools with only four 
in the Pulau Maya area (BPS, 2018). It does not receive many tourists as it is not a tourist city, and the majority of people in Kayong Utara speak three different kinds of Malay and Dayak as their home language (L1) (Sari et al., 2019) with around 50,000 inhabitants speaking Malay in Kayong Utara. They also speak Bahasa as their national language (L2) (Bamba, 2016), while English, in this case, is considered as having a higher prestige within the community compared to four languages mentioned above. Sugono et al., (2011) suggest that people's attitude toward English is influenced by its function in helping the user find employment, even if the people themselves hardly ever speak English.

Although English is a required subject in schools, few students have more than the rudimentary skills required to use the language properly. One of the contributing factors to this is that in a rural area such as Pulau Maya, students do not have an adequate opportunity to be exposed to English outside the classroom in the context of their daily life. In this sense, Pulau Maya could be categorised as a typical rural area in an English as a Foreign Language (EFL) country. Even though some researchers have suggested that learners who can speak more than one language have a higher metalinguistic awareness and that they might be able to learn a third language (L3) faster, they may not learn it efficiently due to interference from their L1 and L2 (Lu, 2013). Additionally, another emerging challenge is that English is barely used at all in students' daily life, and has little presence in rural areas (Gil, 2006).

In order to address this lack of exposure to English, many researchers have suggested solving this issue by raising students' awareness of the elements in their surroundings as a possible way to support their English language learning. The Linguistic Landscape (henceforth LL) can serve as a means to develop students' English proficiency by providing a context, so they can relate the materials they have learnt in class with the actual English use occurring around them. Gorter (2017) suggests the introduction of LL as a new approach to learning English, describing LL as the language that exists around us in textual form (signage), such as place names, billboards, official notices, etc. This method (as Sayer, 2010 concluded in his study), can be used as a pedagogical resource in the EFL classroom to provide students with exposure to English, and to activities which connect the English language they encounter in class to that found in their community environment.

However, it will take considerable effort to make students aware of the English around them and how it can be used as a source of learning. In order to do so, it is a necessity to firstly analyse and describe what LL actually exists and might be useful for students' learning. Therefore, this research aims to investigate the LL as a form of English exposure that students may encounter around the school neighbourhood in Pulau Maya, and the English language teachers' perception of LL if it is to be applied as additional learning resources. 


\section{LITERATURE REVIEW}

\section{Previous studies on linguistic landscape}

In most studies, LL was used to analyse the many aspects of English that exist in certain countries. They can be used to inform the reasons behind the use of English, language change, and the advantages of using LL in future learning. Sayer (2010), for instance, conducted a study on the social meaning of English encountered in Oxaca, Mexico (see example in figure 1 below), and categorised six reasons why people tend to use English to convey messages in public places (namely, because English is advanced and sophisticated, and indicates fashion, to appear cool, sexy, and as it is preferable for expressions of love or subversive identities). Additionally, Backhaus (2006) examined the purpose of using English in official and non-official signs found in Tokyo, Japan. The first function is that of expressing power, while the second is for communicating solidarity and strengthening relations amongst the Japanese. Research in Bangkok, meanwhile, reports growing shifts from Thai and Chinese to English, as well as as an increase in the influences that English is exerting on local languages in public signage (Huebner, 2006). Again focusing on an Asian country, two recent studies in Japan into the use of LL amongst university students suggested that these approaches can be harnessed to analyse student interpretation of the multilingual signage around them (Rowland, 2013; Rowland, 2016).

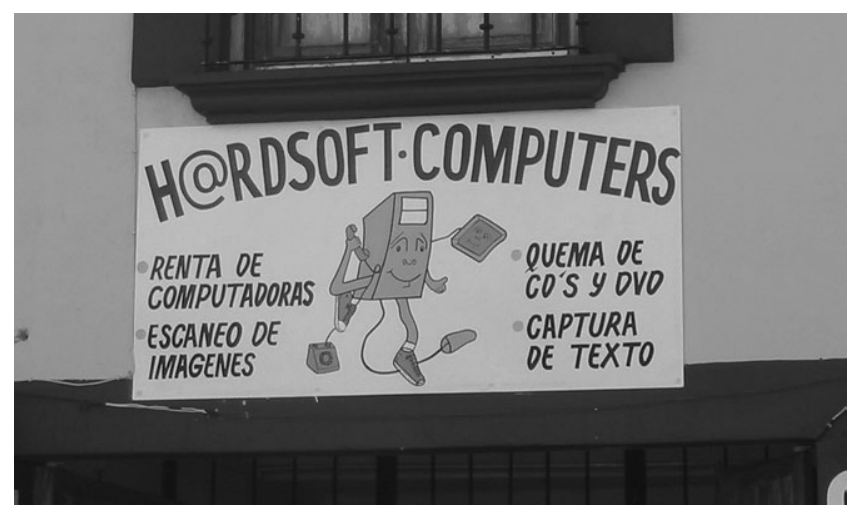

Figure 1. Example of Linguistic Landscape (cited from Sayer, 2010)

However, research on LL can also demonstrate some bias. For instance, Gorter (2006) identifies two major considerations that might negatively affect research in this area if not carefully addressed. The first is in selecting the sample. He suggests that the quantity and location of the sample must be representative of the local town, community or specific area. The second consideration is the definition of LL itself. Each researcher may have their own definition of what constitutes LL. Some may include moving English text (such as that found on buses or a passer-by t-shirt) as a form of LL, others not.

\section{Linguistic landscape}

Landscape, in a broader sense, can be perceived as how people view and interpret meaning from spaces/spheres around them in relation to the social and cultural practice (Jaworski and Thurlow 2010). After initial introduction by 
Voegelin (1933), Gorter (2017) later adapted the term into the field of linguistics which will be known as Linguistic Landscape. The term itself has been widely used as the basis to interpret the holistic situation of linguistics in a certain community.

However, this narrow definition of LL itself can vary depending on the places or spheres in which the linguistic element communicates its meaning. Gorter (2006) explained that in cases where written English is shown in certain public places (such as shopping areas in cities), the term 'Linguistic Cityscape' can be employed. From another point of view, Cenoz and Gorter (2008) prefer to use the term 'Multilingual Cityscape' in the case of the huge number of signs that exist in a commercial, urban area. There may have been a gradual change, nevertheless, on the focus of LL; where it once referred to languages' presence across all regions of a country, now many experts seem concerned primarily with urban areas (Ben-Rafael et al., 2010; Cenoz and Gorter, 2008; Weyers, 2016). One reason for this may well be that - as Kallen and Dhonnacha (2010) argue - in relation to its language and linguistic value, the existence of LL in urban areas has engendered immense problems which need further investigation.

In spite of the many definitions and focuses of LL, the objective of this research is to use the specific understanding of LL and relate it to ELT in rural areas. Therefore, in this study, Linguistic Landscape can be referred to as linguistic objects that mark the public space in any written form of English (BenRafael et al., 2010), and which can be useful for learning English, including road signs, street names, stores, offices, billboards, and so on.

Linguistic Landscape for ELT

In the debate surrounding input for learning, Krashen's (1982) pioneering 'Input Hypothesis' theory describes input as merely 'structures that we have not yet acquired' (p. 21). In his hypothesis, Krashen asserts that the process of acquiring a language can be achieved through exposure to structures beyond one's current competence. Regarding the use of LL as input or learning materials in ELT classes, one of the most significant theories proposed was that of Cenoz and Gorter (2008). They explore the potential of LL through the 'Incidental Learning' theory, defined as the process of acquiring knowledge without any previous intention, or learning one thing while paying attention to something else (Hulstijn, 2003). For example, the learner may acquire some new vocabularies while the main activity was listening to a song. In this matter, Cenoz and Gorter believe that language learning through LL is likely to be incidental. Learners tend to have little or no awareness of the learning process which may be provoked by the English text they encounter in everyday activities. It is important to recognise that, according to Hulstijn (2003), retentional gains in incidental learning may not be overly evident, but by continual exposure to the learning target the result can be tangible.

However, there are some limitations to the correlation of LL as learning input. The first is that of retentional gains. Even though these can be augmented by continuous exposure, this theory depends on some basic factors, such as the frequency with which the learner is exposed to the signage around them (Ellis, 
2008) and whether these signs are relevant to them. Considering the amount of LL present in a certain area, rural (when compared with urban) areas seem to have an insufficient number of signs that learners can see. Moreover, learners as passersby in public spaces could view English signs as something 'given' which they may take for granted (Ben-Rafaelet al., 2010), and no learning process will occur in this case.

The second criticism attached to the approach of using LL as input is that of isolating the effect of LL from other types of input that the learner receives in the process of learning a language. Through conducting controlled laboratory experiments (Gorter and Cenoz 2004), it is possible to identify the role of LL in SLA, but nonetheless difficult to do so (Cenoz and Gorter 2008). Cenoz and Gorter (2008) further emphasise the limitation of using LL in learning a language by saying,

'Even if only those items of language the learner has paid attention to are processed and stored, it would be difficult to know which elements of the linguistic landscape draw the learner's attention and how aware the learner is of paying attention to them' (p. 273).

Nevertheless, the use of LL as additional learning resources has been suggested by some experts to have significant effects on learners' language learning, which can be summarised as follows:

\section{Learners' pragmatic competence}

Exposure to the LL can particularly provide better input at different linguistic levels or competencies. In this regard, pragmatic competence (Kasper \& Rose, 2001) - which refers to the ability to communicate one's intended message, or in this case to interpret the message conveyed by others in a commonly nuanced socio-cultural context - can be further developed through LL analysis. Any written English placed in a public place will tend to include indirect language and metaphors which are sometimes written in full text, but in many cases, will only consist of one word or phrase, and whose meaning is attached to the context in which they are placed (Cenoz and Gorter 2008). Thus, in relation to the relevancy of LL as learning resources, it is the duty of the English language teacher to bring them into the classroom and, together with students, decipher and interpret (Dagenais et al., 2008) their meaning. This is the situation in which (Ellis, 2005) emphasises that explicit knowledge can become implicit knowledge through interaction with environments and negotiation for meaning in the classroom.

\section{Enhance learners' sensitivity to social aspects of language}

Sayer (2010) contends that the study of LL can not only be carried out by the linguists or language researchers, but also by the language learners themselves. This method can be beneficial in terms of providing an exciting way for students to connect their theoretical knowledge with what actually exists beyond their classroom. Calvert and Sheen (2015) suggest that giving students an appropriately challenging and meaningful task can increase their learning engagement. Therefore, such learning methods will help learners develop their sensitivity to 
connotational aspects of language by developing their analytical understanding of how language is used in wider society.

\section{Developing multimodal literacy}

As previously mentioned, LLs can have a positive impact on learners' pragmatic competence and their sensitivity to the social aspects of language. However, as LL appears in the form of written texts, they also relate to literacy skills. Goddard (2002) remarks that literacy cannot be achieved solely through the means of written language. Readers tend to combine texts with various additional media that help them better comprehend their meaning (i.e. sounds, visuals, semiotic symbols). For example, text messages include different types of font, with colour variation and accompanying icons; such combination was later coined multimodal literacy (Cenoz and Gorter 2008). Likewise, LL is considered as multimodal literacy because it combines both visual and written texts. This characteristic blending coupled with the specific location where LLs are placed provide different contexts for the readers (passers-by) to conceptualise the meaning.

By and large, and based on the research findings presented above, it seems reasonable to conclude that LLs can be highly useful in promoting English language learning in the classroom when used under the right circumstances. Sayer (2010) further recommends that this approach be adapted and used by teachers to focus English learning instruction on vocabulary, grammatical features and idioms. The use of LL could even solve learning problems such as insufficient learning resources, and the claim that some learners have low exposure to English. In the case of low student engagement, LL can also be advantageous, since it is authentic and comes from local social contexts that the students can access anytime. As Cenoz and Gorter (2008) explain, '[i]t is authentic in the sense that it is not especially designed for teaching languages but for other purposes' (p. 274).

\section{RESEARCH METHOD}

This study employed a qualitative method. The aims of using a qualitative method are to provide rich and complex description to achieve an in-depth understanding of research participants or an issue of social/educational importance that are being investigated (Denscombe, 2010). To support the methodology, I also employed a case-study approach. The fundamental concept of a case-study is to investigate and report real-life phenomena, including complex and dynamic circumstances (Cohen et al., 2011).

As this research focuses on some areas around one school, including the English language teachers from the school, the results will not be easily generalised to other schools in this region, or to any schools in rural areas, due to this school's specific environment and staff. Nevertheless, Wellington (2000) asserts that the important aspect of a case study is not in making a generalisation of results, but rather on how one relates the case and learns from.

\section{Sample and informants}

This research employed a non-probability sample - namely, purposive sampling. Cohen et al., (2018) describes that purposive sampling also seeks those 
who have in-depth knowledge of something. First, the focus of this research was to investigate the Linguistic Landscape that appears around some specific schools in Pulau Maya. Following the definition provided in the literature review, the investigation focused on signage in the form of written English text that could be categorised as language exposure for students, such as the pictures of store names, street names, T-shirts, advertisements, posters, billboards, etc. Second, this research also aimed to discover how English language teachers perceive the LL as teaching material, and therefore, I conducted an interview with four English language teachers from the selected schools in Pulau Maya.

\section{Instruments}

According to Creswell (2014), in relation to the qualitative method, data can be gathered in many forms (i.e. qualitative observation, qualitative interviews, qualitative documents, and qualitative audio and visual materials). In this research, as the focus is on analysing the linguistic landscape around schools and the perception of English language teachers toward the use of LL for language learning, the data were collected in two forms: (1) by observing the qualitative visual materials; and (2) by conducting semi-structured interviews.

\section{Procedures}

As previously elaborated, the first data that were collected is the photographs of LL, followed by showing the pictures to the English language teachers and asking about their perception of the sample pictures. Harper (2002) describes the use of photographs in interviews as photo-elicitation, in which the researcher uses them as stimulus or reference for questioning. He also argues that the use of this method can stimulate the interviewee to refer back to events or situations that could have been forgotten. In this sense, I used LL photographs to elicit spoken data from the teachers regarding their perceptions of LL for language learning.

\section{FINDINGS AND DISCUSSION}

\section{LL as a form of English exposure}

This section explicates the categorisation derived from the primary source of data which is the LL photographs. Along with this research, 202 English signage photographs have been collected. Using qualitative content analysis (Silverman, 2006) - the process of 'counting the frequency of certain visual elements in a clearly defined population of images, and then analysing those frequencies' (Rose, 2016, p. 88) - I have developed several divisions by adapting themes from existing research (Reh, 2004; Cenoz and Gorter, 2008; Vaish, 2008; Sayer, 2010; Rose, 2016). In short, figure 2 below will summarise the LL categories that I have developed specifically for this study. 


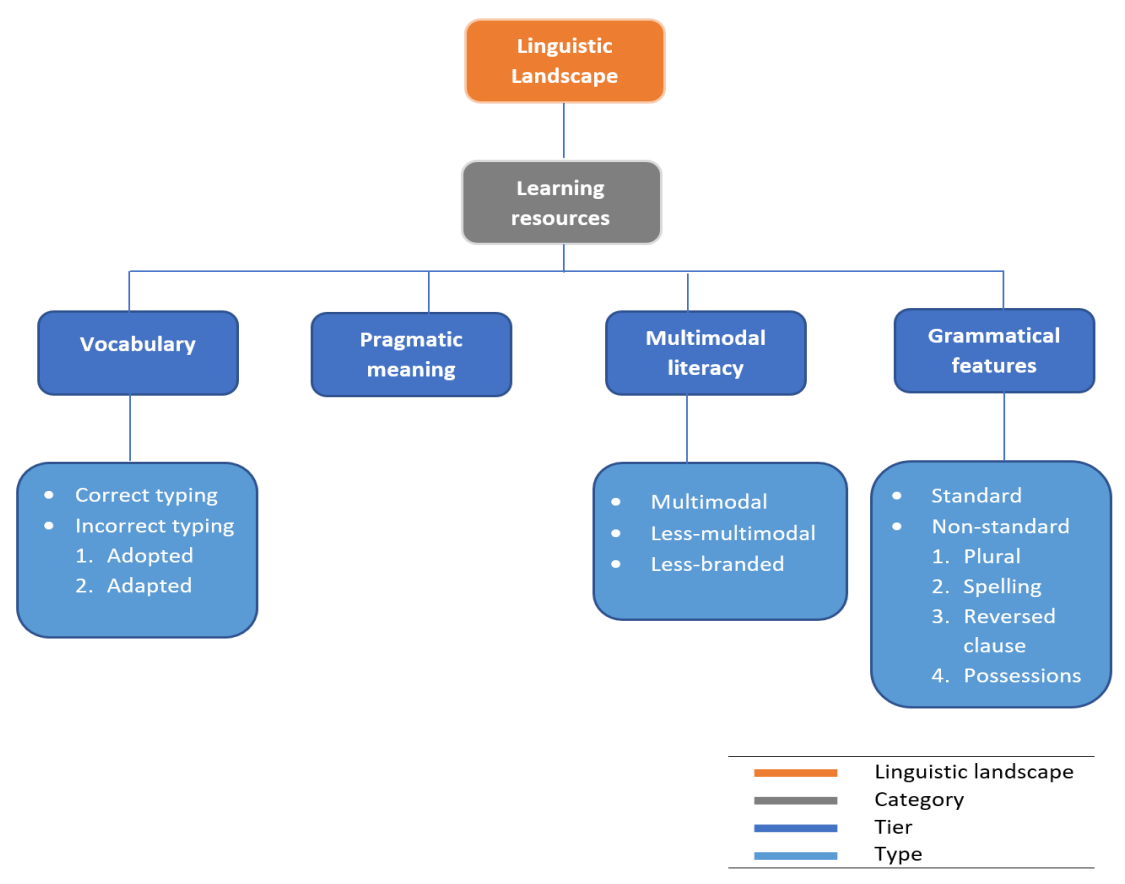

Figure 2. Categorisation of $L L$

This Learning resources category was adapted from Cenoz and Gorter (2008) and Sayer (2010). The division of this category into vocabulary, pragmatic meaning, multimodal, and grammatical features supports the assumption that it the most applicable process of categorising for students or of teacher analysis of LL signs in Pulau Maya. Moreover, these sub-skills generally receive more attention from experts in relation to $L L$ as learning materials.

Table 1. LL Categorisation as Learning Resources

\begin{tabular}{|c|c|c|c|}
\hline Tier & Type & Description & Amount \\
\hline \multirow{3}{*}{ Vocabulary } & Correct typing & No english words are mistyped & 149 \\
\hline & $\begin{array}{l}\text { Incorrect typing } \\
\text { - Adopted }\end{array}$ & $\begin{array}{l}\text { Contain words that are adopted from English with } \\
\text { little or no modification }\end{array}$ & 62 \\
\hline & - Adapted & $\begin{array}{l}\text { Contain english words that are re-written which } \\
\text { suits local pronunciation or just simply mistyped }\end{array}$ & 53 \\
\hline $\begin{array}{l}\text { Pragmatic } \\
\text { meaning }\end{array}$ & & $\begin{array}{l}\text { Contain hidden message(s) that what actually } \\
\text { written }\end{array}$ & 48 \\
\hline \multirow{3}{*}{$\begin{array}{l}\text { Multimodal } \\
\text { literacy }\end{array}$} & Multimodal & Using more than 3 elements/modals in one sign & 145 \\
\hline & Less-multimodal & Using only 3 elements/modals & 43 \\
\hline & Less-branded & $\begin{array}{l}\text { Using only } 3 \text { elements/modals but well-known by } \\
\text { people }\end{array}$ & 14 \\
\hline \multirow[b]{2}{*}{$\begin{array}{l}\text { Grammatical } \\
\text { features }\end{array}$} & Standard & Using correct grammatical forms & 104 \\
\hline & $\begin{array}{l}\text { Non-standard } \\
\text { - Plural } \\
\text { - Spelling } \\
\text { - Reversed } \\
\text { clause } \\
\text { - Possessions }\end{array}$ & Using incorrect grammatical forms, in: & $\begin{array}{c}13 \\
53 \\
6 \\
26\end{array}$ \\
\hline
\end{tabular}




\section{Vocabulary}

In terms of the English vocabulary that I found in LL signs in Pulau Maya, I placed them under two types of writing, which are correct and incorrect typing. Correct typing simply means that the sign contains English words that have no mistakes. I also applied this specification to all signs, whether in full English, or only containing two or three English words. There are 149 out of 202 signs which meet this criterion, i.e. more than $70 \%$ have correct English vocabulary. For example, the use of the word Fashion in Cinta Fashion (figure 13), with the English word Fashion and the rest of the text in Bahasa.

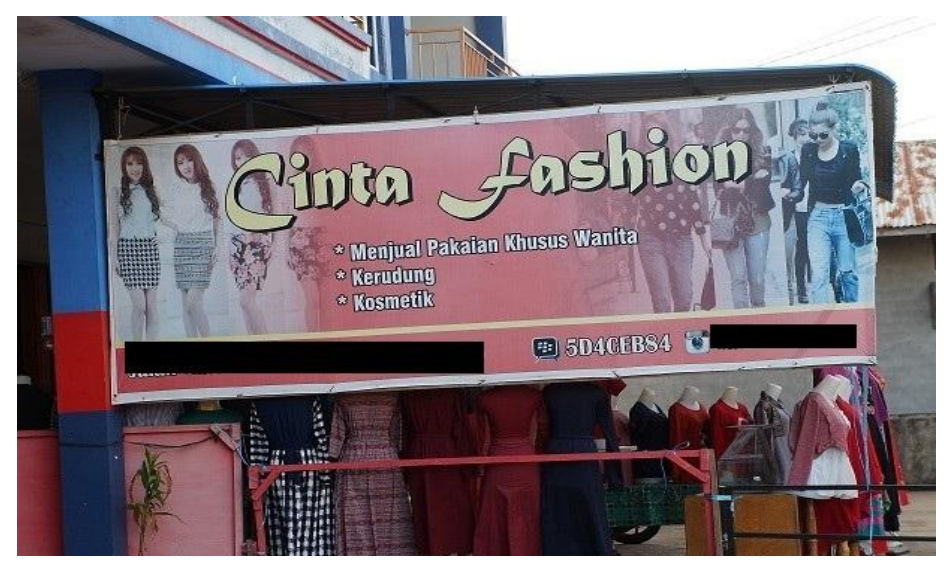

Figure 3. Correct typing sign

The second type is incorrect typing, which I divided into two more subthemes: adopted and adapted. Both of these themes could share the same signs, as LL signs in Pulau Maya were typically descriptive, containing a lot of informative text. Therefore, one sign could be categorised as adapted and adopted at the same time. The first theme, adopted, is much the same as loanwords, or words that are borrowed from English with little or no modification. 62 signs were found that have similarities to this criterion. Offered as an example is the sign from a local electronics store (figure 14) that tried to use English words combined with Bahasa, but actually the word in Bahasa is derived from English (KREDIT = CREDIT, or a method of deferred payment). The second theme is adapted, meaning the use of English words that are rewritten to suit local pronunciation, or simply mistyped. There are 53 signs can be categorised as having adapted language. For example, the sign from a mobile top-up outlet that included English within the sign, but mistypes the words (figure 15). The sign states PULSA ALL OPRATOR-ACCECORRIS (PULSA means credit or balance), where it should read PULSA ALL OPERATORS-ACCESSORIES. Such a mistake indicates that the owner might consider the form OPRATOR as the most convenient to type, based on its phonetic translation rather than the correct spelling. 


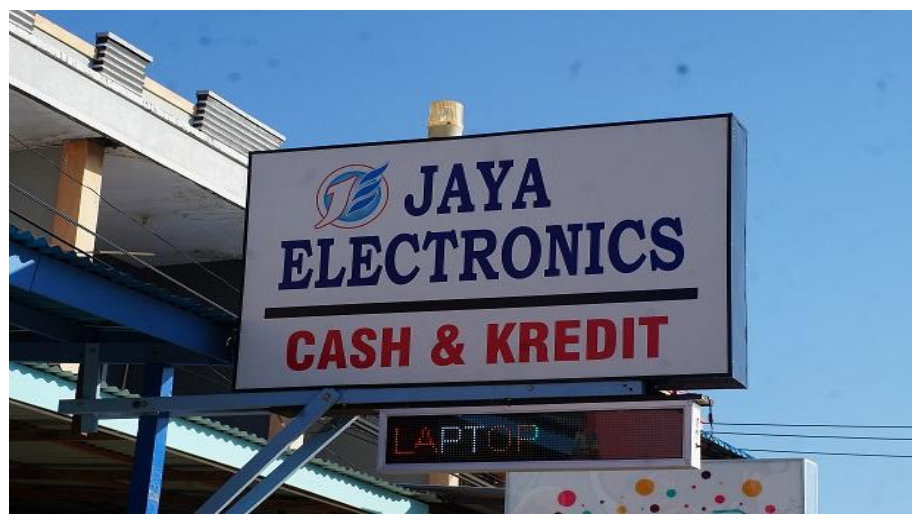

Figure 4. Incorrect-adopted sign

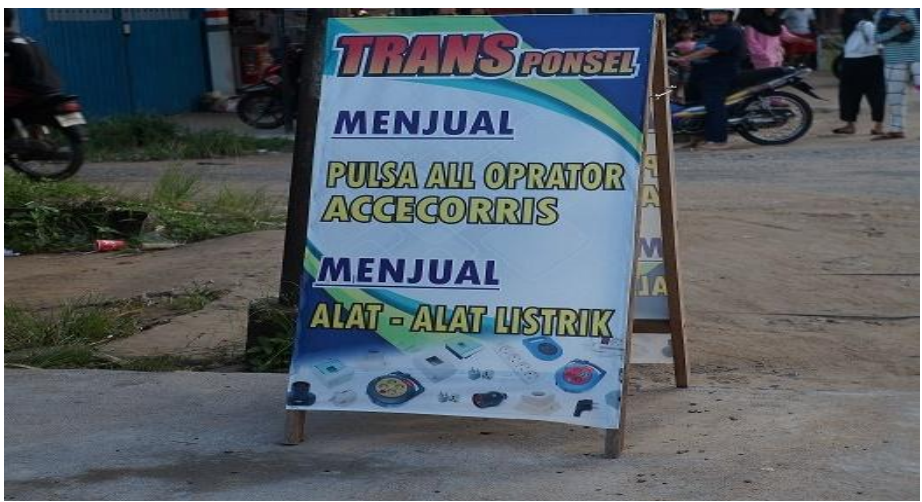

Figure 5. Incorrect-adapted sign

\section{Pragmatic meaning}

The second tier is pragmatic meaning. In this study, pragmatic refers to any LL signs that contain a hint or hidden message that needs other modalities or background knowledge to interpret its meaning. Cenoz and Gorter (2008, p. 274) mention that ' $[\mathrm{t}]$ exts written in the public space tend to include different speech acts and often use indirect language and metaphors'. In this regard, like other scholars, I believe that the pragmatic meaning contained in signs could provide input for English language learners. As Dagenais et al., (2008) mention, pragmatic LL could become learning resources when teachers bring the signs into the classroom and, together with the students, decipher and interpret the meaning. There are 48 signs that contain this pragmatic meaning, such as my HOMEBASE (figure 16). This sign is very simple in design and did not include other extra information of what messages this sign wanted to convey. However, the inclusion of the signal reception symbol could imply to the reader that this sign is trying to inform them that the location where it is placed provides wi-fi access, as often found in a café. 


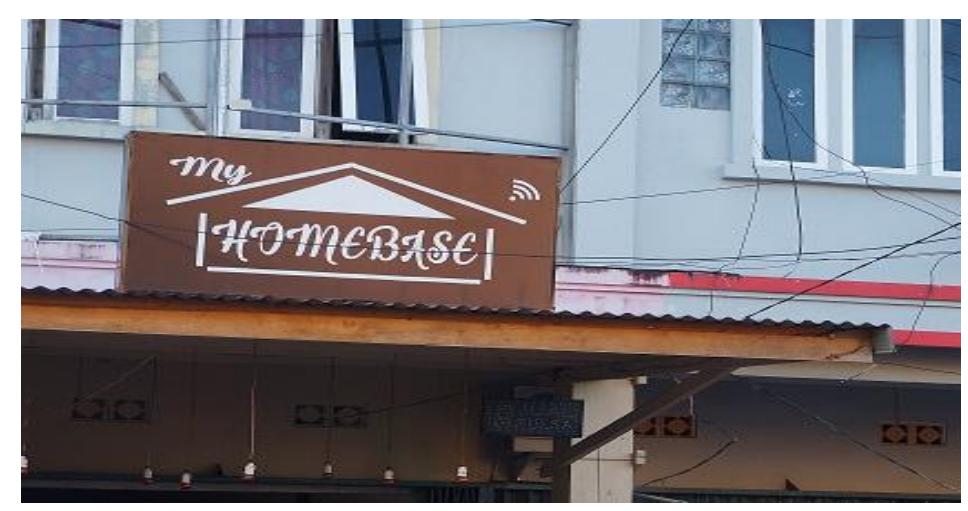

Figure 6. Pragmatic sign

\section{Multimodal literacy}

Additionally, interpreting LL signs cannot be separated from the way in which passers-by read the sign (i.e. literacy). In this study, I define multimodal as the integration of visual elements, i.e. texts, fonts, colours, images, logos, shape, materials, and space of the sign. Based on these elements, I separated this tier into multimodal, less-multimodal and less-branded types.

The first type is multimodal, which (as elaborated above) incorporated more than three basic elements (texts, fonts, and colours) in one sign, while the elements of shape, material and space are already considered to be possessed by every sign. This type receives the highest proportion compared to other types, totalling 145 signs. For example, the sign of a local laundrette (figure 7) combines five elements, including a picture of clothes that have been washed along with fabric softeners, and an icon of a washing machine giving a thumbs-up. The second type is less-multimodal, which I define as signs that only use the basic elements of modalities. There are 43 signs in the area of investigation that could be categorised as less-multimodal. For example, the sign of a small retailer that sells credit for mobile phone providers (figure 8). This sign consisted of text with the same font choice, coloured in black and red.

The last type is what I call as less-branded, in which the signs only use the basic elements but are still easily recognised by people due to the iconic meaning that they show. There are 14 signs that match this criterion, for example, the sign of VIVO product (figure 9) that only consists of text, fonts, and colours. However, the typical choice of fonts and colours could transfer the meaning easily to the passers-by, as most will understand that the sign belongs to a worldwide mobile phone brand. 


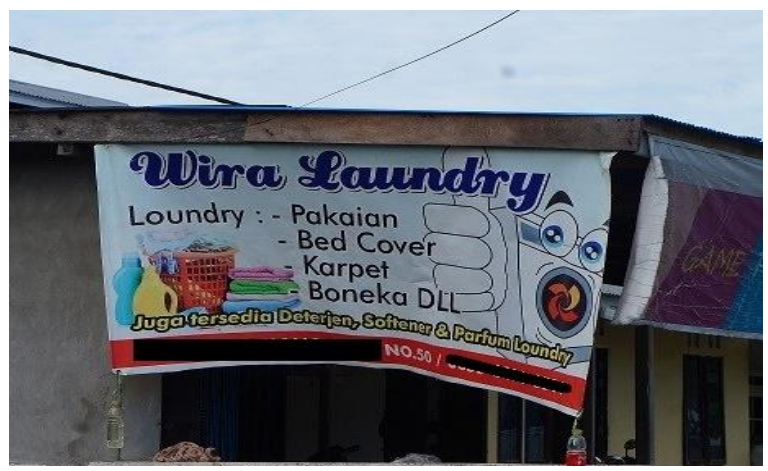

Figure 7. Multimodal sign

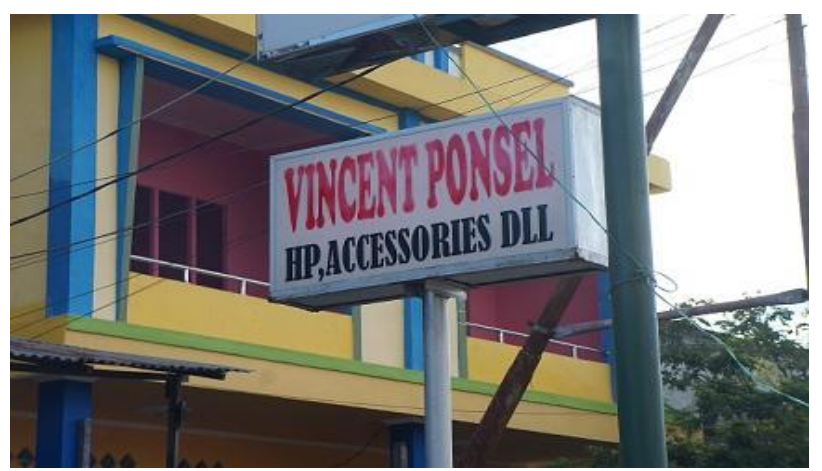

Figure 8. Less-multimodal sign

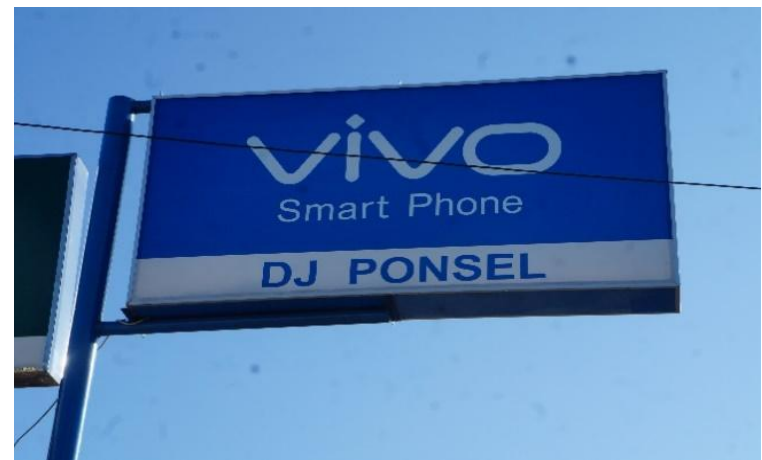

Figure 9. Less-branded sign

\section{Grammatical features}

The last tier that could be useful for learning materials is that of grammatical features. Sayer (2010) suggests that this tier could be adapted to a classroom learning situation where the students are asked to undertake an analysis of the English around them in the form of signs. He further explores their potential use in analysing the grammatical features (both standard and nonstandard), which include the spelling, possessions, and compound words. This tier is divided into standard and non-standard grammatical forms, where the latter could be specified as examples of incorrect plurals, spelling, reversed clauses, and possessions.

The first type is standard grammatical features, where the signs used correct grammatical forms. 104 signs were considered to be standard. In most signs, the use of correct grammar predominantly stemmed from national/multinational 
companies, presumably as they may have more carefully considered and chosen which English words they were going to include in their advertisements. In some others, the standard grammar came from local businesses which only used one or two simple English words and thus did not require too much grammatical attention. One of the standard grammatical forms is the sign from the ISUZU car distributor (figure 10) that is being used by a local motor workshop with the English text, GENUINE PARTS.

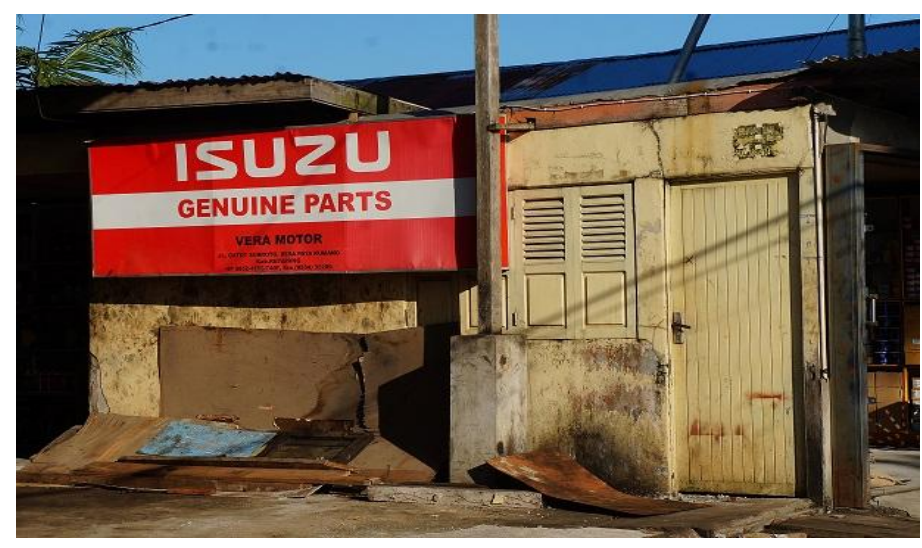

Figure 10. Standard grammatical sign

The second type is non-standard grammatical features. The ubiquity of incorrect English grammar is evident throughout the analysis, as nearly 50\% of the LL signs are non-standard. The first classification is the incorrect use of plurals. There are 13 signs that suit this criterion, with all of the signs missing the suffix -s in indicating the plural form. The most salient examples are in the phrases ALL OPERATOR and SPARE PART. Take, for instance, the sign from a top-up retailer encouraging passers-by to join their business and become an agent in selling mobile credit for its users (figure 11). The second non-standard grammatical feature is spelling. Although this feature - proposed by Sayer (2010) - has the biggest number compared with other non-standard features, it is quite similar to the tier Vocabulary - adapted (discussed earlier), which contains mistyped English words.

The third classification is the reversed clause, for example, an adjectivenoun phrase that is not in the correct order (figure 22). This mistake can also happen when the signs' producer uses typically Indonesian grammar, in which the word order is commonly noun-adjective. The last classification is possessions, mistakenly used in 26 signs. These mostly failed to show the belonging of one's property, especially when the signs incorporated the owner's name in the name of the place, for example, Mirra salon (figure 23) where s/he did not use 's to indicate possession, i.e. that the salon that belongs to Mirra. This mistake can be referred to as failure in using plurals or possessions, depending on the perspective and the intention of the owner. 


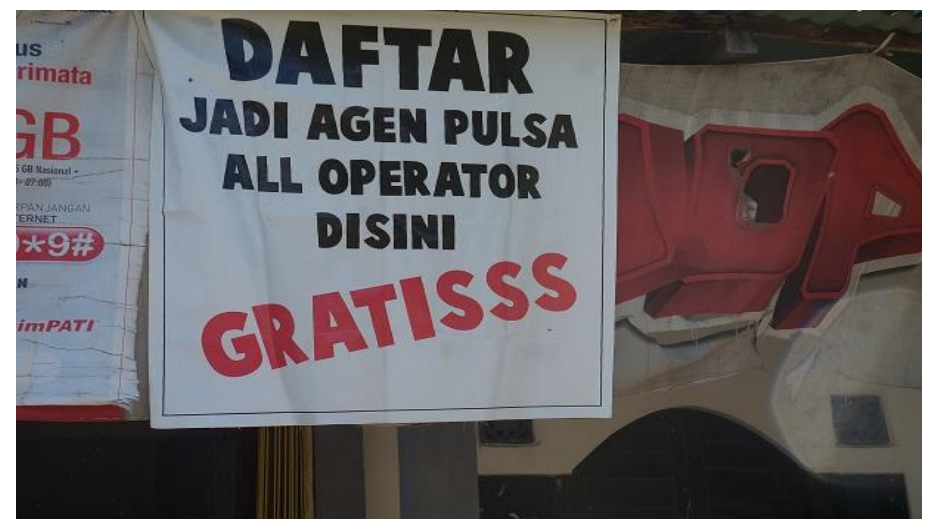

Figure 11. Non-standard plural sign

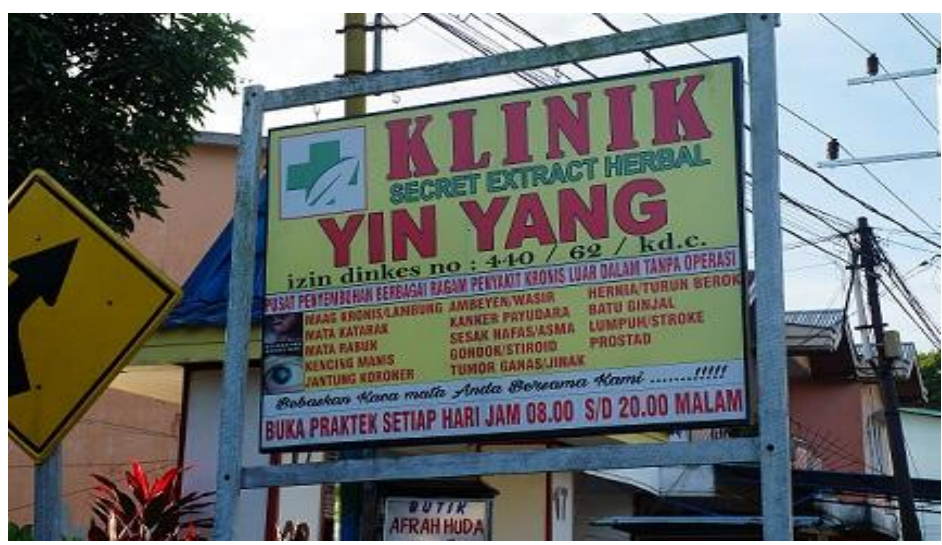

Figure 12. Non-standard reversed clause sign

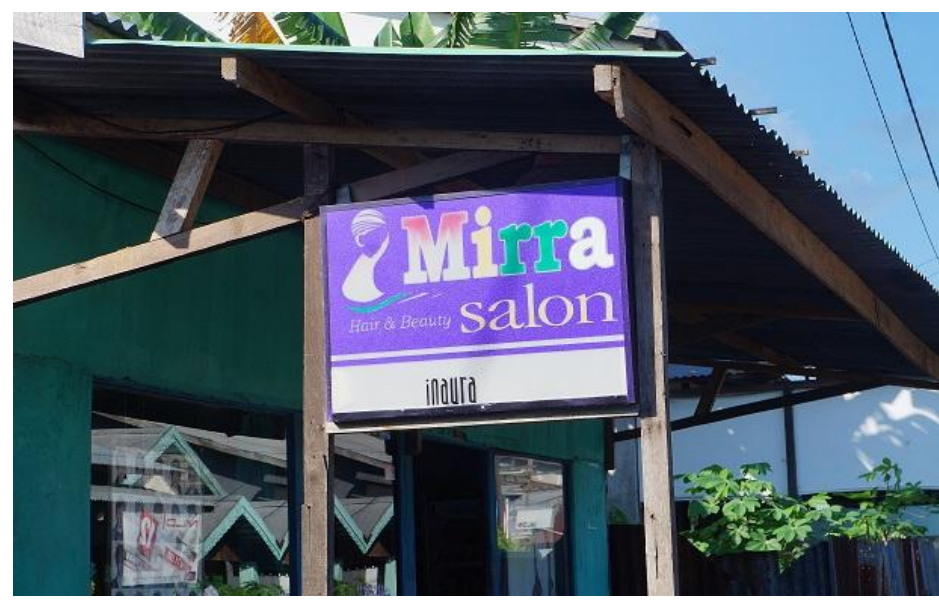

Figure 13. Non-standard possessions sign

\section{Teachers' perceptions}

This second analysis explores the teachers' perspectives toward the use of LL in the classroom to facilitate English language learning. The data presented in this section were derived from teachers' interviews which have been fully transcribed (Cohen et al., 2018). In total, there were four participants, with each participant speaking for about twenty minutes, which was recorded. 
The analysis begins with exploration around the themes that have been developed, followed by direct quotations from participants, where relevant. Four themes regarding the teachers' perspectives will be discussed: teaching strategies; challenges for teaching in Pulau Maya; insights regarding LL; and LL in connection with K-13. The classification of the number of the teachers involved when expressing certain opinions can be regarded as, 1 teacher $=$ One; 2 teachers $=$ some; 3 teachers $=$ most; and 4 teachers $=$ all.

\section{Teaching strategies}

To begin the analysis on teachers' perception of LL, the exploration of how they choose teaching strategies in the classroom is considered to be the first topic to discuss. Most of the teachers believed that before they apply any methods or strategies to teach English, they need to establish a good psychological relationship with the students. They mentioned that gaining the students' interest and trust is their paramount priority.

\section{P2: I tried to take their hearts, I tried to build an emotional foundation with the students, [which] I believe, if I give them some space or a little freedom, and then they trust me, it will be okay for me to push them further in their learning.}

The typical strategy they use is to do brainstorming before the lesson begins, which attempts to stimulate the students' prior knowledge and coax them into engaging with the related materials of the day. For the main learning activity, most of the teachers prefer to use what they believe are engaging and fun activities, such as guessing some English expressions by a gesture, roleplaying to express love, or trying to connect the materials with other subjects. One teacher remarked:

P3: Well, when the material is about expressing love, they feel that it's a fun activity, because I wasn't asking them to simply read and pronounce the expression, but to actually act how to express love. Then, when they do the expression, the rest of the class will feel embarrassed and then they will laugh together.

This choice is probably caused by the classroom situation, where the teachers assert that the students' motivation to learn English is very low. However, the same teacher also reported that when using this type of activity, there is an imminent drawback, which is that of time constraints, adding:

\section{P3: No, there's not enough time for that. In a week, the time allocation for the English subject is two hours of lessons. The one-hour lesson consists of 45 minutes. So, the total is only 90 minutes for me to teach English.}

As I further investigated, I found an appalling fact regarding the teaching situation in these schools. The reality is, the newest government-designed curriculum is not evenly applied across all grades in the school. During the time of interview, only the first grade was using the K-13 curriculum, while the second 
and the third grades were still using the KTSP curriculum. This is quite interesting, considering that the government regulation to use $\mathrm{K}-13$ has been in place since 2013, and it has still not been fully applied by this school. Hence, the time allocation for teaching English is different between the K-13 class and the KTSP class, with the former only receiving 2 hour-long lessons per week, and the latter 4 hour-long lessons in a week.

\section{Challenges for teaching in Pulau Maya}

Most of the teachers agreed that there are at least four major factors that contribute to the low engagement of the students, namely: the society or environment, family, the students themselves, and the resources to support their learning. There was a feeling, however, that the salient factor is the students' attitude toward English in Pulau Maya particularly, which regards English as something that is almost outlandish to learn, or even as something absurd if they try to imitate spoken English. Lightbown and Spada (1999) describe this problem as a 'social dynamic or power relationship between the languages' (p. 57), where a member of a minority group could have a unique attitude when learning the language of a majority group such as English.

\section{P1: And in the society here, they just think that 'English is a foreign language and if you can speak it, that is good, but if you don't, well, it's okay'.}

There was also a mixture of responses when the teachers were asked how they overcome those problems. One recommended giving the students a direct talk to motivate them to learn English, while another teacher asked them to join an English club organised by the school, or even used a 40:60 ratio of English and Bahasa in the classroom, but none of these seems to have had a meaningful impact.

\section{Insights regarding $L L$}

When the teachers were shown some sample pictures of LL around the school, their opinions were varied. Some of them were even quite surprised that there were actually English signs around them which they had never actually paid attention to before. One teacher commented that it is common that people incorporated English into signs, however, the sign-makers do not fully understand how to use English. This situation showed that even teachers are not fully aware of the existence of English in other forms (signs) around them, which could also imply the students' lack of awareness of the same issue.

At first, when they were asked their opinions about whether or not LL could be used as additional learning resources, they responded differently. Some of them were pretty sure that such a potential source of learning could help them in the teaching process, while others were quite sceptical.

P2: Well, it depends on the students. If they are quite good at English, I will give it to them. If they are not so good at it, it will distract them a lot. For example, I already told you about some loan words from English to Bahasa. For some students, they 
cannot differentiate which one is the right one. It's easier for them to remember the wrong one.

These perspectives are probably driven by the fact that there are mistakes in the use of English within the sample pictures, a matter which concerns the teachers if the students see it as the correct form of English. However, some other teachers believe that constant exposure to such English (LL) will benefit them in many ways.

P3: I can make use of it. I can teach them how to make it correct, for example, which will also increase their curiosity toward English. They can also become more aware, for example, of the wrongly written words.

\section{LL in connection with $K-13$}

As previously discussed, not all teachers in these schools teach under the guidance of the K-13 curriculum. Therefore, questions regarding this topic were not asked to every teacher. The first question for analysis is whether or not this LL method can be useful to support the aim of K-13. Some teachers seemed to agree with this notion and commented that this approach could provide students with analytical skills that connect the materials they have studied in the classroom with the English that actually exists in the environment around them.

Another teacher similarly admitted:

P2: I think it will support the curriculum itself, because it will make the students try to analyse what happens around them and then try to decide by themselves. So, they will not only depend on the teacher. I think it will make them quite critical as well.

Interestingly, although they agreed that LL could help support the K-13, this teacher also does not wholeheartedly approve of the implementation of this current curriculum. P2 showed their strong remarking:

P2: I believe that actually our curriculum totally sucks. To be honest, it really sucks, because when I tried to compare it with the curriculum during my time in secondary school in 2007, I began to wonder, how can they survive?

Another commentary from a different teacher disputes the notion that LL can support the K-13 curriculum.

P1: I don't think so, because English is not their second language, and they still regard it as a foreign language. The curriculum needs English to be academic and formal, where the goal is to teach them so they can speak English correctly and fluently, but in here [pointing at LL pictures] there is some incorrectly written English. 
Despite the negative views on the use of LL (or even on the curriculum itself), the potential benefits of using the surrounding signs to promote English language learning have largely been acknowledged by the teachers. Such perceptions could also be affected by the minimal comprehension of most of the teachers as to the purpose of the K-13 curriculum - which Ahmad (2014) refers as a discrepancy in perceiving curriculum goals among teachers - since only one teacher out of those interviewed has been trained by the government to implement the curriculum. There are, however, some limitations of LL if it is to be applied to the current situation in Pulau Maya. One teacher said that LL could only be used as a brainstorming activity to begin the class, or as a hook for the core materials. However, another teacher admitted that the limitations came from the teacher themselves:

P3: Even though I teach English, I'm not very sensitive to this sort of thing, and that would be my homework to figure this out. Even me as a teacher, I don't have the sensitivity of this, let alone my students.

It is interesting to note that among the debates surrounding the implementation of the K-13 curriculum, the teacher could see the benefit of LL. They only have differing interpretations and methods of how best to use it within their own teaching practice. In summary, although the LL signs are pervasive around this specific area in Pulau Maya, the analysis shows that English teachers in this school are not aware of it and have never used such methods to teach English in the classroom, or adapted it as additional learning resources.

\section{CONCLUSION}

This study sought to explore the existence of signs that incorporated English into their basic elements in one of the rural areas in West Borneo, Indonesia, which can be considered as an EFL country. These signs make up what I call the Linguistic Landscape (LL). The final focus of this research is to relate the findings of LL signs that exist in a particular area in Pulau Maya with the teaching activity in the selected schools. Therefore, this research tries to connect the LL signs with classroom teaching activities by interviewing some English language teachers. Some teachers seemed to agree with the notion of using LL signs as additional learning materials. They believe that learning resources could come from many origins, even those outside of the classroom. On the other hand, another teacher commented that these signs are not appropriate to be used as learning materials in the classroom. This teacher further added that the signs contain incorrect English, which will affect the students' understanding of English itself. Such a fact would probably cause the students to easily accept that what is written on the signs is the correct form of English, even though it is actually wrong. However, as discussed above, even containing the incorrect form of English, this method could still be applicable to the teaching-learning process in the classroom. It is worth noting that in all cases, the teacher should always guide their students to critically analyse those signs and make corrections if necessary. I believe that this method is also in line with the K-13 curriculum that requires the students to understand multiple types of text that suit the local context. 
These research findings show that in a rural area such as Pulau Maya although a sample area - there were numerous signs that incorporated English. These signs were then analysed and categorised into several classifications which I believe could be useful for English language learning. Even though the signs were evident, there were some sceptical perceptions from the teachers as to how this LL method could be applied as additional learning material in the classroom. Despite this negative view, all of the teachers seemed to acknowledge that LL could benefit the language learners. Finally, I believe that this method would be in line with the current curriculum in Indonesia (K-13) Finally, further research that incorporates students as participants is also suggested, alongside the expansion of research to other rural areas.

\section{ACKNOWLEDGMENTS}

This research was ostensibly supported by Indonesian Ministry of Research, Technology and Higher Education through the Penelitian Dosen Pemula (PDP) scheme 2020.

\section{REFERENCES}

Backhaus, P. (2006). Multilingualism in Tokyo: A look into the linguistic landscape. International Journal of Multilingualism, 3(1), 52-66.

Bamba, J. (2016). Institut Dayakologi: The challenges of an information and advocacy centre. In Z. I. Victor T. King (Ed.), Borneo studies in history, society and culture of Dayak culture in Kalimantan (pp. 313-340). Singapore: Springer.

Ben-Rafael, E., Shohamy, E., \& Barni, M. (2010). Introduction: An approach to an 'ordered disorder. In E. Shohamy, E. Ben-Rafael, \& M. Barni (Eds.), Linguistic landscape in the city (pp. xi-xxvii). Bristol: Channel View Publications.

BPS, K. U. (2018). Kabupaten Kayong Utara dalam angka [North Kayong regency in numbers]. Kayong Utara: BPS-Statistics of Kayong Utara Regency.

Calvert, M., \& Sheen, Y. (2015). Task-based language learning and teaching: An action-research study. Language Teaching Research, 19(2), 226-224.

Cenoz, J., \& Gorter, D. (2008). The linguistic landscape as an additional source of input in second language acquisition. International Review of Applied Linguistics in Language Teaching (IRAL), 46(3), 267-287.

Cohen, L., Manion, L., \& Morrison, K. (2011). Research Method in Education ( $7^{\text {th }}$ ed.). New York: Routledge.

Cohen, L., Manion, L., \& Morrison, K. (2018). Research methods in education ( $8^{\text {th }}$ ed.). New York: Routledge.

Creswell, J. W. (2014). Research design: Qualitative, quantitative, and mixed methods approaches (4th ed.). London: SAGE Publications. 
Dagenais, D., Moore, D., Sabatier, C., Lamarre, P., \& Armand, F. (2008). Linguistic landscape and language awareness. In E. Shohamy, \& D. Gorter (Eds.), Linguistic landscape: Expanding the scenery. London: Routledge.

Denscombe, M. (2010). The good research guide : for small-scale social research projects $\left(4^{\text {th }}\right.$ ed.). New York: McGraw-Hill Open University Press.

Ellis. (2005). Principles of instructed language learning. System, 33(2), 209-224.

Ellis, N. (2008). Implicit and explicit knowledge about language. In J. Cenoz, \& N. H. Hornberger (Eds.), Encyclopedia of language and education Vol. 6 (pp. 119-132). London: Springer.

Gil, J. (2006). English in minority areas of China: Some findings and directions for further research. International Education Journal, 7(4), 455-465.

Goddard, A. (2002). The Language of advertising: Written texts ( $2^{\text {nd }}$ ed.). London: Routledge.

Gorter, D. (2006). Introduction: The study of the linguistic landscape as a new approach to multilingualism. International Journal of Multilingualism, $3(1), 1-6$.

Gorter, D. (2017). Linguistic landscapes and trends in the study of schoolscapes. Linguistics and Education, 1-6.

Gorter, D., \& Cenoz, J. (2004). Linguistic landscapes and L2 learners in multilingual contexts. (pp. 8-11). San Sebastian/Donostia, Basque Country, Spain: EUROSLA 14 (European Second Language Association Conference).

Harper, D. (2002). Talking about pictures: A case for photo elicitation. Visual Studies, 17(1), 13-26.

Huebner, T. (2006). Bangkok's linguistic landscapes: Environmental print, code mixing and language change. International Journal of Multilingualism, 3(1), 31-51.

Hulstijn, J. (2003). Incidental and intentional learning. In C. Doughty, \& M. Long (Eds.), The Handbook of second language acquisition (pp. 349-381). Malden: Blackwell Publishing.

Jaworski, A., \& Thurlow, C. (2010). Introducing semiotic landscapes. In A. Jaworski, \& C. Thurlow (Eds.), Semiotic landscapes: Language, image, space (pp. 1-40). London: Continuum International Publishing Group.

Kallen, J. L., \& Dhonnacha, E. N. (2010). Languages and inter-language in Urban Irish and Japanese linguistic landscape. In E. Shohamy, E. Ben-Rafael, \& M. Barni (Eds.), Linguistic landscape in the city (pp. 19-36). Bristol: Channel View Publications.

Kasper, G., \& Rose, K. R. (2001). Pragmatics in language teaching. In K. R. Rose, \& G. Kasper (Eds.), Pragmatics in language teaching (pp. 1-10). Cambridge University Press.

Kemendikbud, K. P. (2013). Kerangka dasar dan struktur kurikulum sekolah menengah atas/madrasah aliyah [Basic framework and curriculum 
structure of senior secondary school/madrasah aliyah]. Jakarta: Kementerian Pendidikan dan Kebudayaan [Ministry of Education and Cultures].

Krashen, S. D. (1982). Principles and practice in second language acquisition. California: Pergamon Press Inc.

Lightbown, P. M., \& Spada, N. (1999). How languages are learned ( $2^{\text {nd }}$ ed.). Oxford: Oxford University Press.

Lu, J. (2013). English learning in chinese minority areas: The challenges and new directions. Theory and Practice in Language Studies, 3(4), 556-563.

Reh, M. (2004). Multilingual writing: A reader-oriented typology - with examples from Lira Municipality (Uganda). International Journal of the Sociology of Language , 1(170), 1-41.

Rose, G. (2016). Visual methodologies : an introduction to researching with visual materials (4th ed.). London: SAGE.

Rowland, L. (2013). The pedagogical benefits of a linguistic landscape. International Journal of Bilingual Education and Bilingualism, 16(4), 494-505.

Rowland, L. (2016). English in the Japanese linguistic landscape: a motive analysis. Journal of Multilingual and Multicultural Development, 37(1), 40-55.

Sari, M. Y., Muzammil, A. R., \& Syahrani, A. (2019). Khazanah leksikon kelautan dalam bahasa melayu dialek Sukadana [Marine lexicon repertoire in malay language of Sukadana dialect]. Jurnal Pendidikan dan Pembelajaran Khatulistiwa, 8(3), 1-9.

Sayer, P. (2010). Using the linguistic landscape as a pedagogical resource. ELT Journal, 64(2), 143-154.

Setkab, H. (2015, October 22). 122 Daerah ini ditetapkan pemerintah sebagai daerah tertinggal 2015 - 2019 [List of 122 underdeveloped regions in Indonesia 2015-2019]. Retrieved October 22, 2020, from http://setkab.go.id/122-daerah-ini-ditetapkan-pemerintah-sebagai-daerahtertinggal-2015-2019/

Silverman, D. (2006). Interpreting qualitative data : methods for analysing talk, text and interaction (3rd ed.). London: SAGE.

Sugono, D., Utomo, I. B., Hardaniwati, M., \& Subiyatningsih, F. (2011). The language attitude of border peoples Insular Riau, West Kalimantan, East Kalimantan, North Sulawesi, and the Eastern Sunda Islands. Wacana: Journal of the Humanities of Indonesia, 13(1), 166-184.

Vaish, V. (2008). Biliteracy and globalization. In B. V. Street, \& N. H. Hornberger (Eds.), Encyclopedia of Language and Education vol 2 (pp. 119-130). London: Springer. 
Voegelin, C. F. (1933). Review of language and languages: An introduction to linguistics by Willem L. Graff. (W. L. GRAF, Ed.) American Anthropologist, 35(2), 356-358.

Wellington, J. (2000). Educational research : contemporary issues and practical approaches. London: Continuum.

Weyers, J. R. (2016). English shop names in the retail landscape of Medellín, Colombia. English Today, 32(2), 8-14. 